\title{
Corporate Governance and Stakeholder Conflict
}

Final version at: http://link.springer.com/article/10.1007/s10997-010-9135-4

\author{
MICHAEL CARNEY \\ John Molson School of Business \\ Concordia University, \\ 1455 de Maisonneuve Blvd. West, \\ Montréal, Québec, Canada \\ Phone : +1 (514) 848-2424 x 2937 \\ Fax : +1 (514) 848- 4292 \\ E-mail: mcarney@jmsb.concordia.ca \\ ERIC GEDAJLOVIC \\ School of Business \\ Simon Fraser University, \\ Vancouver, British Columbia, Canada \\ E-mail: erg@sfu.ca \\ SUJIT SUR* \\ School of Business \\ Dalhousie University, \\ 6100 University Avenue \\ Halifax, Nova Scotia, Canada \\ Phone: +1 (902) 494-4589 \\ Fax : +1 (902) 494-1107 \\ E-Mail: sujitsur@dal.ca
}

\section{Version Revision 101 \\ 2/3/2013 3:32 PM \\ * Corresponding Author}




\section{Authors' Biographies}

Michael Carney (PhD, University of Bradford, UK) is Concordia University Research Chair in Strategy and Entrepreneurship and professor of management at John Molson School of Business, Concordia University, Montréal, Canada. He is currently a Senior Editor at Asia Pacific Journal of Management. His research has been published in Entrepreneurship: Theory and Practice Journal of Management Studies, Management and Organization Review, Organization Studies and Strategic Management Journal among others. His research focuses upon Asia's family owned business groups and he recently completed a book on the topic entitled Asian business groups: Context governance \& performance, published in 2008 by Chandos.

Eric Gedajlovic holds a joint appointment with the strategy and innovation and entrepreneurship areas at Simon Fraser University, Vancouver, Canada. His research focuses on entrepreneurship and the comparative analysis of business, financial and governance systems and their influence upon the development of firm capabilities and national competitiveness. Eric's research has been published in leading international journals such as Academy of Management Journal, Strategic Management Journal, Journal of Management Studies, Organization Science, Journal of International Business Studies, Journal of Business Venturing and Organization Studies.

Sujit Sur holds a joint appointment with the strategy and international business areas at Dalhousie University, Halifax, Canada. His research focus upon corporate ownership and international governance, and their implication for firm performance. Sujit's research has been presented at Academy of Management, Strategic Management Society and Decision Sciences Institute, as well as published in the proceedings of European Group for Organizational Studies, Administrative Sciences Association of Canada, and Eastern Academy of Management. 


\title{
Corporate governance and stakeholder conflict
}

\begin{abstract}
The stakeholder management literature is dominated by the 'shareholder value' and 'inclusive stakeholder' views of the corporation. Each views the governance problem in terms of inter-functional conflicts between stakeholder groups such as between investors and managers or managers and employees and rests on the assumption of an idealized corporate structure characterized by the separation of ownership from management. Our review of corporate governance and stakeholder conflict shows that such functional based characterization is too simplistic and fails to account for important intra-functional conflict. Through a comparative review that considers managerial, stakeholder and family systems of governance, we demonstrate that while the modality of conflict varies by system, substantial intra-functional conflict is endemic to each. We integrate the findings of the agency and comparative stakeholder theories of corporate governance to offer an authority based framework with three different governance structures that offers complementary insights into stakeholder conflicts. Thus, our study highlights the important, but often neglected intra-stakeholder type of conflict in various organizations and provides a basis for understanding their various manifestations and consequences under the different systems of governance.
\end{abstract}

Keywords: Stakeholder Salience, Stakeholder Theory, Shareholder Value, Governance Systems. 


\section{Introduction}

Beggars do not envy millionaires, though of course they will envy other beggars who are more successful.

-Bertrand Russell

Russell's observation on the resentment that can attend those sharing the same condition reminds us of a point all but forgotten in the management stakeholder literature, namely that stakeholders who seemingly share a common fate are frequently in conflict with one another. Rather than united in common cause against a more powerful other, like brothers in arms, they can be more like Cain and Abel, jealously divided against one another. Contemporary corporate governance is primarily concerned with conflicts between stakeholder groups, such as owners, workers, and managers, or what Wolfe and Putler (2002: 298) describe as role-based stakeholder groups. Conversely, we show in this paper that the corporate governance literature identifies settings for numerous conflicts within stakeholder groups or intra-stakeholder conflicts, such as those among owners (Bergloff \& von Thadden 1994; Hoskisson, Hitt, Johnson, \& Grossman 2002) or creditors. However, while there are several compelling explanations of interstakeholder conflicts, such as agency theory (Eisenhardt 1989) or class politics (Roe 1994), there is no comparable account of intra-stakeholder conflict.

We address the issue of intra-stakeholder conflict from the perspective of an authority approach. Through a comparative review that considers managerial, stakeholder, and family systems of governance, we show how patterns of authority inherent in each in system privileges by according salience to distinct classes of stakeholders and increases their capacity to achieve their interests. In this regard corporations can be understood as venues for distributional contests 
among stakeholders (Edwards 1979; Fiss \& Zajac 2004). The idea that firms are venues for distributional contests will surprise few readers yet this aspect of governance is rarely investigated. Indeed, Hinings and Greenwood claim that management theory has lost interest in how 'privilege and disadvantage are distributed within organizations' (2002: 411). With a focus upon incentive alignment, managerial oversight, and codes of practice - much corporate governance research focuses on mitigating inter-stakeholder conflict with a view to maximizing corporate performance and firm value (Dalton, Daily, Certo, \& Roengpitya 2003). Yet phenomena such as minority shareholder expropriation, executive salary premia, opaque accounting practices, unfunded pension liabilities, and related party transactions indicate that value is often appropriated and redistributed among stakeholders before it appears in bottom line performance measures (Coff 1999). Recurrent corporate scandals highlight the contested nature of stakeholder relationships as they periodically propel corporate governance practice into the mainstream of political debate.

We propose that intra-stakeholder conflicts are inherent in the functioning of a firm and because stakeholder primacy varies with the governance system, so does the very definition of governance issues - whether as a means of resolving conflicts, or being the very cause of the conflict. The fundamental issue of corporate governance is not simply one of protecting shareholders from managers, rather the issue is one of determining stakeholder distribution rights, describing inter-stakeholder tensions, and identifying the means through which the primary stakeholders seek to preserve their privilege and externalize the costs of those privileges onto less powerful secondary stakeholders.

One intended contribution of this paper is to advance the idea that 'above the bottom line' value distributions to stakeholders depend decisively upon a firm's corporate governance system. Such 
contests among stakeholders to capture value can be manifest in either financial or non-financial gains or losses. For example, executives may prefer to take value in the form of perks (Zajac \& Westphal 1994) and employees may seek compensation through job security, flexible terms of employment, vacation time or career development opportunities. In this respect we seek to explain stakeholder salience, which is 'the degree to which managers give priority to competing stakeholder claims'(Mitchell, Agle, \& Wood 1997: 854). Whereas Mitchell et al (1997) propose that salience is a function of stakeholder attributes of power, legitimacy, and urgency we argue that stakeholder salience is influenced largely at the firm level by attributes of its corporate governance.

In the following sections, we briefly review existing perspectives on inter and intra stakeholder conflicts in the governance literature highlighting the shortcomings therein. Subsequently, we develop the notion of authority based governance systems and demonstrate how it can be used to shed new light on intra-stakeholder conflicts. Thereafter, we review literature linking stakeholder salience peculiar to each governance system, and conclude with suggestions for future research.

\section{Inter- and intra-stakeholder conflict}

\subsection{Agency Perspective}

The prevailing perspective on corporate governance is agency theory which holds that differences in owner and manager interests arising out of the separation of ownership and control, constitutes the major stakeholder conflict in the modern corporation (Jensen 1989; Jensen \& Meckling 1976). While separation of ownership and control represents an efficient specialization of function (Fama \& Jensen 1983) professional managers with little or no ownership stake in the firms they manage make decisions on behalf of shareholders but have 
little incentive to manage the firm efficiently, or in a manner consistent the interests of its shareholders. The solution to the conflict is essentially contractual in nature: namely executive compensation through incentive contracts combined with board and stock-market oversight (Useem 1993). In this shareholder value maximization conception of the firm, contractual solutions are recommended and extended to other stakeholders wherein each of the firms' constituencies, "labor, capital, suppliers, customers, the community, and management- ... are better advised to perfect their relations to the firm at the contracting interface at which the firm and their constituents strike their main bargain" (Williamson 1985: 298). Such a solution conceives of the firm as little more than a nexus of contracts (Williamson, Aoki, \& Gustafsson 1990) in which inter-stakeholder relations are expected to be inherently adversarial (Roe, 1994).

Notwithstanding the growing normative acceptance for shareholder value maximization, at the heart of the managerial governance model is the expectation that managers will continue to serve themselves first\{Hansmann, $2004 \# 8597\}$. The tension between shareholders and managers over value allocation has lately shifted away from the design of incentives toward the intensification of monitoring and accountability. Much formal governance reform is crisis driven (Coffee 2000) and the recent scandals in the US have created a momentum for legislative change. US legislation such the Sarbanes Oxley act of 2002 that strengthens disclosure requirements was enacted in the wake several corporate scandals in which executives were manifestly manipulating incentive systems in their own favor. However, stronger reporting requirements is not always in the interest of some organizations, for example, information disclosure by high-tech firms may harm their competitive positions, and disclosure can also hinder the restructuring of mature enterprises. Consequently, intensified disclosure requirements may have precipitated a move toward private equity (Engela, Hayes, \& Wang 2007). Behind the 
movement toward private equity is the intent to strengthen equity holders' claim over residual value and does little to improve outcomes for other stakeholders.

Thus, while the focus of agency driven governance is the conflict between stakeholder groups, there are a few instances of assessment of intra-stakeholder conflicts. The tension between creditors and equity holders is well documented (Harris \& Raviv 1991; Jensen \& Meckling 1976) wherein the debt contract gives equity holders an incentive to invest sub optimally. However the agency theorists' concern still remains minimizing managerial opportunism, and the recommendations focus on the optimization of debt holding by trading off the "agency cost of debt against the benefit of debt" (Harris \& Raviv, 1991: 301).

Recent literature also points towards the potential of conflict between majority and minority equity holders, commonly known as the Principal-Principal Agency (PPA) or Type 2 agency concerns, especially in the context of emerging economies (Dharwadkar, George, \& Brandes 2000), and dual class shareholding (Jarrell \& Poulsen 1988). There are also a few studies looking at the difference in outcome preferences between different types of owners (Thomsen \& Pedersen, 2000), and long-term (pension fund) and short-term (mutual-fund) investors (Hoskisson, Hitt, Johnson, \& Grossman 2002). However, the underlying governance concern remains the agency driven maximization of shareholders' return and/or minimization of managerial self-serving behavior.

This view of inter-stakeholder tensions has much to recommend it but it is partial and oversimplified. Our comparative review of governance systems suggests a more fine-grained perspective that identifies and highlights numerous intra-stakeholder tensions, for example, between minority and controlling investors, equity investors and creditors, knowledge workers and routine workers, senior and new employees, owner-managers and professional managers, 
and insider and arm's-length buyer/suppliers. Different governance systems privilege distinct classes of shareholders in terms of their capacity to achieve their investment goals, monitor performance, and enforce their claims (Thomsen \& Pedersen 2000). Similarly, governance systems also differ in their tendencies to accommodate bargaining and power dynamics that in turn influence stakeholders' abilities to extract firm value.

\subsection{Stakeholder theory perspective}

Traditional approaches to stakeholder management tend to view distributional contests in terms of gross role-based categories (Wolfe \& Putler 2002) such as tensions between investor and employee outcomes or between management and employees (Freeman 1984; Pfeffer 1994). These role-based stakeholder groups are assumed to share similar priorities and interests within the group. Ironically, Freeman (1984) the doyen of stakeholder theory, has warned against assuming homogeneity of interests among such groups and argued that stakeholder theory ought to identify specific points of differentiation within seemingly homogenous groups. However, only very few studies have gone beyond generic role-based definitions - the majority assume homogeneity of interests and priorities within role-based stakeholder groups (Wolfe \& Putler, 2002). While the stakeholder management concept promises insight on how managers might balance their responsibilities to shareholders and other interests who hold a legitimate stake in the firm (Freeman 1984), the reconciliation of competing claims has proven difficult.

In particular, the logic of shareholder wealth maximization has been inhospitable to the stakeholder a view of the firm. One key text declares "mutually beneficial stakeholder relationships can enhance the wealth-creating capacity of the corporation" (Post, Preston, \& Sachs 2002: 36). However, empirical support for this view is mixed (Berman, Wicks, Kotha, \& 
Jones 1999; Donaldson \& Preston 1995; Hillman \& Keim 2001; McGuire, Sundgren, \& Schneeweis 1988). In addition, critics of stakeholder theory point out that managers in "such systems have no way to make principled or purposeful decisions" (Jensen, 2002). Furthermore, stakeholder theorists, especially proponents of normative and instrumental approaches often become embroiled in arid debates about the primacy of shareholder wealth maximization versus a broader conception of business ethics (Freeman, Wicks, \& Parmar 2004; Sundaram \& Inkpen 2004). In this respect, descriptive stakeholder theory scholars focus almost exclusively upon stakeholder outcomes in the publicly-held firm where important corporate decisions are made by professional managers (Jones \& Wicks 1999). By focusing upon single corporate type, such research on stakeholder theory essentially holds corporate governance as a constant. In so doing, significant variation in stakeholder and organizational outcomes in other systems of governance are overlooked.

To summarize, theories of corporate governance typically adopt either an agency/shareholder (Jensen 2000) or stakeholder/socio-political approach (Fligstein 2001) to address issues of performance and efficiency. Table 1 highlights the key findings and major differences between these perspectives.

Table 1 about here

The agency or shareholder-centric approaches focus upon questions relating to the incentives and allocation of decision rights among managers and providers of capital (Jensen 1998) and are preoccupied with addressing a narrow range of agency problems stemming from 
that relationship. On the other hand, socio-political approaches adopt a wider perspective invoking society (Fligstein, 2001), politics (Gourevitch \& Shinn 2005), class (Roe 2003), and history (Bebchuk \& Roe 1999) to explain continuing differences in national systems of corporate governance. While possessing great face validity socio-political approaches to governance often say very little about the practice of administration (Aguilera \& Jackson 2003). We reason that to the extent that agency theories reduce to a concern with dyadic relations in the absence of context, and because socio-political theories reify the host society, then both streams flow away from a concern with organizations, their primary activities and purposes, and the distribution of outcomes for the stakeholders.

To address the issue of stakeholder conflict we adopt an organization-centric and comparative governance approach that puts the firm at the center of its analysis (Aguilera, Filatotchev, Gospel, \& Jackson 2008). We describe our perspective as an authority approach that incorporates elements of both agency and socio-political theories of corporate governance. Whereas Aguilera et al's (2008) approach focuses upon the costs and contingencies of particular corporate governance practices; we focus instead on the effects on stakeholders of the authoritative hierarchical order inherent in any governance system. In the following section, we elaborate on our authority based governance model, grounding it in existing literature and highlight how this approach might be better positioned to explain intra-stakeholder conflicts.

\section{An authority based approach to governance}

Our authority-based approach addresses a long-standing debate in the stakeholder management literature. This literature has reached an impasse between advocates of 'shareholder value' and 'inclusive stakeholder' views of the corporation (Jensen 2002; Kochan \& Rubinstein 2000). The 
academic stalemate rests on the assumption of a singular, idealized corporate structure characterized by the separation ownership and management, which ignores the diversity of corporate governance systems found around the world. On the other hand, the varieties of capitalism literature (e.g. Hall and Soskice, 2001; Lazonick and O’Sullivan, 2002; Whitley, 1999) sheds light on important institutional-level issues such as the incidence and prevalence of governance types in particular societies and their implications for national competitiveness. However, there are limits to the extent to which institutions can explain patterns of corporate governance (Roe 2003). This is because de jure formal institutions often have little de facto impact on administrative practice (Khanna, Kogan, \& Palepu 2003). Moreover, comparative approaches to corporate governance typically assume that each variety of capitalism will produce an 'emblematic firm' (Boyer 2005), such as the widely-held managerial enterprise, that will predominate in liberal market economies.

Our authority approach to corporate governance recognizes the heterogeneity of corporate governance systems within any particular institutional context. For example, while the widely-held managerial enterprise is prevalent in liberal market economies there is also significant presence of private equity-held managerial enterprise and a long tradition of familycontrolled firms (Anderson \& Reeb 2003). In practice, within any institutional architecture there will typically exist a plurality of 'pure' and 'hybridized' governance systems that consist of combinations of formal, rationally designed or selected instruments and informal, socially structured elements that 'bundle' together in various ways (Young, Peng, Ahlstrohm, Bruton, \& Jiang 2008). Some governance bundles are socially or economically infeasible and rarely found whereas other governance bundles become prevalent and diffuse across societies. Our comparative review focuses upon stakeholder salience under three systems: managerial, 
stakeholder, and family governance. Other systems of governance such as not-for-profit or cooperative ownership certainly do exist, but the three systems reviewed here appear to be the most prevalent in capitalist economies (De Jong, 1995; La Porta et al., 1999). In addition, government or state controlled enterprises though commonly found are not considered in this review, as governance in such entities is more a function of geo-political and national agendas, rather than fundamental business principles.

Each governance system differs with respect to efficiency and performance characteristics but we do not to enter into the debate about the causes of diffusion and prevalence of governance systems in particular societies, rather our purpose is to describe the organizational link between governance and stakeholder salience. Our authority approach is inductive and recognizes that 'particular configurations of hierarchy-market relations' (Whitley 1992) constitute systems of governance that have become prevalent and institutionalized in capitalist economies. Systems of governance determine how authority is shared and allocated within organizations. Authority sharing is the extent to which 'owners and top managers delegate considerable discretion over task performance to skilled employees (and) with suppliers, customers and competitors in varied inter-firm networks \{Whitley, 2007 \#11338\}(Whitley, 2007: 149). In this regard authority may be widely shared among the firm's internal and external stakeholders or centralized in the hands of a single individual.

In managerial governance, ownership and management control is separated and but professional managers' discretionary authority is bounded by a series of checks and balances and managers must justify their actions on the basis of shareholder welfare (Charkham 1994). Authority most widely shared under stakeholder governance, ownership and management control 
is separated but executives of a focal firm share authority with external stakeholders such as buyer/suppliers and capital providers who make mutual commitments to one another thereby embedding control in a network of enduring relationships. Stakeholder governance also delegates significant discretion over task organization to skilled employees and typically invites their participation in decision-making processes $\{$ Whitley, $2007 \# 11338$ \}. Stakeholder governance is often referred to as "insider", or "network" governance (Charkham 1994) and is sometimes equated with either the Japanese, or Germanic systems in which complex and durable intercorporate networks have featured prominently. Due to its decoupling from stock-market oversight and long term relational linkages with a main bank and employee groups in the form of lifetime employment and employee co-determination, stakeholder governance most approximates what scholars would identify as the stakeholder model of the firm (Sabel 2004).

In family governance, managerial authority and capital provision are concentrated and in the hands of the same individuals. The exercise of authority is largely unchecked since ownermanagers are making decisions with their own money (i.e. exercising their property rights). The concentration of authority enables the firm to serve as an instrument that reflects the personal value systems of the entrepreneur and family members (Gedajlovic, Lubatkin, \& Schulze 2005; Schulze, Lubatkin, Dino, \& Buchholtz 2001). Owner-managers decisions do not need to be justified to outsiders and because they view the firm as 'our business' (Demsetz \& Lehn 1985) they may project their own idiosyncratic vision onto the business (Chua, Chrisman, \& Sharma 1999).

The structure of authority also dictates the contracting mode, which refers to prescribed norms about the way business transactions are conducted. Contracting mode varies in terms of whether transactions between the firm and resource providers are regulated by arm's length 
formal rules, or more tacit agreements and relational norms (Macneil 1978; Poppo \& Zenger 2002). The former reflects a highly calculative rationality wherein actors 'attempt to consider all possible means to an end and weigh the alternative means in a decision making calculus' (Biggart \& Delbridge 2004: 11). Managerial governance tends towards the arm's length side of this dimension and emphasize making transactions publicly transparent and on the establishment of formal mechanisms for enforcing contracts and settling disputes (Biggart \& Delbridge 2004). Stakeholder governance relies more extensively on relational contracting among its resource providers and transactions are governed by tacit agreements, and socially embedded practices with unspecified time horizons (Hamilton \& Biggart 1988; Ring \& Van De Ven 1992). Under family governance, owner-managers have greater freedom to exercise their discretion in utilizing either contracting mode. Owner managers can use their social capital to transact in their social networks for financial and managerial resources, and business opportunities (Carney 2005). Alternatively, owner-managers may adopt a highly instrumental and arm's length approach to contracting (Uzzi 1997). In the following sections, we elaborate further on each governance system and the stakeholder salience specific to it.

\section{Governance systems and stakeholder salience}

The salience of stakeholder claims on management attention has been viewed as a stakeholder attribute (Mitchell, Agle, \& Wood 1997). In contrast, our authority approach proposes that firm corporate governance will determine an enduring legally prescribed and/or socially sanctioned stakeholder hierarchy regarding the rights and claims to the value created by the firm. Stakeholder salience specifies primacy or 'who really benefits' from the firm's activities through kinds of rewards and incentives that can be legally and legitimately attained under specific 
governance systems. In the following sections we distinguish between primary and secondary stakeholders and show how the stakeholder hierarchy engenders an array of both inter and intra stakeholder conflicts that are endemic to specific systems of governance.

\subsection{Stakeholder outcomes under managerial governance}

The great virtue of managerial governance is its capacity to simultaneously provide equity investors with the liquidity of their capital and participation in returns from long-term investment. It is this dual shareholder benefit that lies behind large liquid capital markets that allow for the emergence and persistence of managerial governance (Rappaport 1990). Firms characterized by managerial governance make greater use of public equity markets than other types of firms. Thus, the majority of capital is supplied by diversified arm's length suppliers who are concerned with returns on their portfolios rather than the performance of any one investment (Shleifer \& Vishny 1997).

The primary role-based stakeholder conflict is between equity investors and executives. The authority structure arising from separated ownership and management vests strategic decision rights with professional managers who serve as agents for widely dispersed and diversified shareholders and to whom they hold a fiduciary duty. However, arm's length investors are vulnerable insofar as they have neither the ability, nor by virtue of their small holdings in any one firm, the incentive to monitor managers (Kester 1992). This core agency

problem recognizes that the interests of managers and shareholders diverge in certain circumstances suggest that salaried executives tend to pursue expansion strategies and/or consume a variety of perquisites that benefit them at the expense of shareholders (Jensen \& Meckling 1976). Due to its delegated authority, structure professional managers possess access to critical 
information and tacit knowledge of the firms operations and have significant opportunity to capture value.

To contain potential agency problems in managerial controlled firms, an array of capital market instruments and agencies have emerged to redress the power of managers. Fligstein (2001) describes the ideology behind these developments as the rise of the shareholder value conception of control and its principal mechanism is an active market for corporate control to constrain managers. Factors such as the rise of institutional investors, the growth of blockholding, and active-private equity firms are designed to mitigate the free-rider tendencies of dispersed ownership. Acting collectively these institutional agents are unencumbered by any loyalty to a specific family or company and are able to extract greater value than they had been receiving under the 'unchallenged rule of managerial capitalism' (Useem, 1993: 237). Yet these institutional investors also have the potential of agency issues wherein the fund managers might make suboptimal decisions for their shareholders (Woidtke 2002).

In the past few decades there were attempts to align investor-manager incentives through stock options or similar mechanisms that make a portion of top executive pay contingent upon stock market performance (Hall \& Liebman 1998). However, many factors outside the control of executives can influence corporate financial performance (Finkelstein 1992). Thus, a potential cost to executives of being remunerated largely based on performance incentives is that they must assume some downside risk in compensation that is not attributable to their ability or effort levels. These executives also face a serious threat of dismissal if market returns are viewed as unsatisfactory (Walsh \& Seward 1990).

Attempts to minimize employment risk suggest managers will seek control over their firms' compensation processes and negotiate the structure of their compensation so that vesting 
and capitalization occur in the near term (Combs \& Skill 2003). Executives may also capture value in the form of selectively designed incentive compensation (Porac, Wade, \& Pollock 1999), or by back-dated grants of stock options (Arya \& Sun 2004; Lie 2005). In the US that the vast majority of stock-options are cashed on vesting (Blasi, Kruse, \& Bernstein 2003). Thus, equity linked executive compensation can also be part of the agency problem itself. For example, managers may divert value to themselves through a variety of mechanisms, such as self-dealing and insider trading (Bebchuk \& Jolls 1999) or managers may adopt but not implement the substance of long term incentive plans by symbolically managing shareholder perceptions and decoupling external and internal processes (Westphal \& Zajac 1998). Whereas shareholders possess a legal claim on firm value, they are primary stakeholders, but senior executives also achieve primacy due to an authority structure that accords them sufficient power to pursue their interests.

Secondary stakeholders: Because executives who wish to access capital on public markets on the most favorable terms they may find it necessary to accommodate suppliers of financial capital and the exercise of this imperative often come at the expense of suppliers and employees. Under managerial governance, secondary stakeholders' outcomes are attained through calculative arms-length contracts contractual means. Managerially governed firms tend to utilize instrumental pay-for performance systems for employees that heavily weight rewards toward specific behaviors or measurable outcomes, such as hourly pay, piece rates or sales commissions. As a consequence of their arm's length and instrumental orientation these firms often hire and fire workers with a calculative rationality in response to changes in technology or market conditions (Jacoby \& Mitchell 1990). Consequently, they present their employees with significant employment risk without the corresponding upside accorded senior executives 
(Hoskisson \& Turk 1990). Employees are likely to reciprocate their employer's calculative rationality with respect to firm tenure, maintaining employment alternatives and developing generic, occupational and professional skills that increase their value on external labor markets(Waterman, Waterman, \& Collard 1994).

Intra-stakeholder conflicts between employees are evident under managerial governance where the principle of seniority mitigates some effects of labor market flexibility for employees with long tenure. Seniority is prevalent in the UK, USA and Canada where it is applied in practices related to lay-off, recall and promotions (Post, Preston, \& Sachs 2002). Seniority backloads rewards for employees who commit themselves to idiosyncratic firm specific learning. However, seniority effects are most prevalent in declining and hypercompetitive industries such as airlines where two-tier wage systems are common (Heetderks \& Martin 1991). Intrastakeholder conflicts are also evident between knowledge workers and routine employees. In these circumstances highly skilled and 'star' employees may be offered 'pieces of the action' (Rousseau \& Shperling 2004) in the form of stock options and as a means of securing their continuing contribution.

However, a contractual approach to employees provides managerially governed firms with skilled workers whom they may readily hire and fire. On the other hand, because employees may sell their services to the highest bidder, the prevailing wage for high performers and those offering scarce resources can be significantly higher than in systems where job security and firm tenure is more highly valued by employers and employees. Hence, employee stakeholder outcomes may rise and fall depending upon the urgency of the demand for their services but the variability of their outcomes stems from a secondary status in the stakeholder hierarchy (Mitchell, Agle, \& Wood 1997). 
Equally, the firm-supplier relationship has been the subject of much transactions cost analysis and the competitive advantages of long-term cooperation is a virtue often extolled (Dyer \& Singh 1998). Yet managerially governed firms are constrained in their capacity to privilege their supplier relationships. Consequently, the default position in such relations is that suppliers tend to be selected upon considerations of value, price and functional efficacy at the expense of other considerations (Dyer 1996). Professional managers are accountable to shareholders and it is difficult for them to justify tacit and extra-contractual commitments or partner selection upon relational or intuitive criteria (Mintzberg 1994). Contracts with suppliers, distributors and other partners tend to be formalized, precise and complex to account for foreseeable contingencies (Williamson, 1985). Contracts also tend to be discrete and pertain to clearly defined activities over a specified period (Ring \& Van de Ven, 1992). The precise terms will tend to reflect the relative bargaining power of the parties at a given point in time. The risk of shifting power and the potential for opportunism it creates manifests in a preference for joint ventures structured as autonomous third parties that are governed by clearly designed partnership agreements, carefully allocated property rights, value appropriation rules and clear exit options (Kogut 1988). Indeed, business partners may be considered as tradeable options \{Folta, $2002 \# 11340\}$ The potential for opportunism limits firms' commitments to one another and leaves each to seek new buyer/suppliers and to transfer their business if better contractual returns are offered or if partners begin to falter in their performance. Managerial firms have sought to incorporate elements of the relational model into their supply chain management practices yet a highly calculative rationality prevails (Gereffi 2001).

Creditors too possess only a secondary status in managerial governance since they are limited to a contractual stake in the firm. Creditors are exposed to the risk of opportunism, for 
example through accelerated dividend payment schedules (Williamson, 1985). For instance, banks typically will establish long-term contracts that are secured against specific, earmarked assets holding a predictable residual market value (Copeland, 1986). Creditors have few rights of participation in managerial corporate governance indeed, U.S. legal doctrines impose costs on banks for participating in governance through board membership (Krosznera \& Strahan 2001). Since creditors are confined to structuring debt contracts, they have little capacity to influence value allocation. Creditors may participate in corporate governance only in circumstances of distress, such as Chapter 11 style reorganizations, where creditors are granted rights to renegotiate contracts with several other stakeholders and where the risk of opportunism is intensified. Generally, shareholder-creditor conflicts are more pronounced under managerial governance than in other corporate governance systems (Renneboog \& Szilagyi 2008).

\subsection{Stakeholder outcomes under Stakeholder Governance}

Stakeholder governance, like its managerial counterpart, is characterized by the separation of ownership and control and an extensive use of professional salaried executives with little or no ownership stake in the firms they manage. However, the agency problem of managerial discretion constrained and limited by the embedding of executives in the network of relational contracts with a wider constituency of interests. The enduring nature of relational contracting often manifests itself in the cross ownership of patient, non-liquid equity (Dyer, 1996). Consequently, executives are less accountable to and insulated somewhat from capital market pressures and their primary focus is on promoting stable and growing business relations between the organization and its key partners (Walsh \& Seward 1990). As buyer/suppliers often own each other's shares and have recurring commercial ties, there are multiple means of 
monitoring and sanctioning top executives who perform their job poorly or who violate relational norms.

Under stakeholder governance, capital and buyer/suppliers contributions are frequently bundled as partners may supply financial resources to a firm in the form of equity holdings, trade credit, loans and guarantees. In such circumstances, the economic significance of their equity ownership may be less significant than other linkages s (Gerlach 1992). A great strength of stakeholder governance is that it facilitates forging enduring ties between suppliers of capital and focal organizations. Central to these ties, is the mitigation of oversight from financial markets in exchange for "insider" status within the firm (Berglöf \& Perotti 1994). As relations are conditioned by norms and incentives favoring long-term reciprocity, mutual support in the form of inter-temporal smoothing often takes place (Gerlach 1992). For instance, stronger partners may exercise forbearance in leveraging their superior bargaining power and may even prop up faltering buyer/suppliers through loans, or favorable contractual provisions because of the credible expectation that these actions will be reciprocated should the need arise (Allen \& Gale 2000). In Japan, financial institutions tend to bail-out firms that are part of their keiretsu and there is also an ongoing transfer of profitability from high to low performing firms in these networks (Gedajlovic \& Shapiro 1998). Thus, contracting between firms operating under stakeholder governance tends to be much less discrete, formalized and less specific with respect to returns and performance expectations than those found under managerial governance.

The underlying labor and managerial contract, at least for core employees, is similarly relational based upon enduring mutual commitment. The emphasis on growth and stability enhances job security inducing in employees a willingness to invest in companies specific skills (Hall \& Soskice 2001). In return, stakeholder firms are less likely to use individual high-powered 
incentives, more likely to use system rewards such as seniority, profit sharing and annual cash bonuses. To the extent that employees view the firm as an institution, they may evoke a normative orientation that encourages identification with the firm. Perceived labor-management goal congruence facilitates commitment to continuous improvement processes and self-directed team designs (Barker 1993). In such a context, incentives rewarding loyalty and dependability are offered in the form of salaries tied to seniority and firm performance and there is less reliance on pay for performance incentive systems.

Secondary stakeholders Relational contracting with insider stakeholders promotes goals of growth and stability. However, insider influence attenuates pressures to maximize market value to the detriment of equity investors who are relegated to secondary status. This occurs because the interests of equity investors can significantly diverge from suppliers of finance who are also buyer/suppliers. Contributors of finance, either through credit, equity or loan guarantees who are buyer/suppliers have multiple ways of benefiting from their association with the firm, but arm's length suppliers of capital have only one (Gedajlovic \& Shapiro, 2002).

For instance, shareholders-buyer/suppliers may take their benefits in the form of favorable trade arrangements and externalize the cost of those benefits onto arm's length investors. Alternatively, insiders and buyer/suppliers may redistribute profit by transferring financial resources from more to less profitable firms thereby depriving arm's length shareholders in high profits firms from a return on their investment. To the extent that arm's length investors perceive this risk, it will be priced into the financial instrument and make raising capital on public markets more costly.

Moreover, commitment to insiders however, also creates a set of incentives that favors organizational persistence over financial performance and risk aversion over risk taking (Meyer 
1989). If managers and employees develop firm specific assets, their alternative employment opportunities are reduced and they are likely to prefer organizational survival to high-risk ventures that may threaten the firm's existence. A similar rationale applies to dedicated suppliers or customers who intermesh their value chain with a focal organization. Thus 'the interests of elite owners may be subordinated to the interests of non-elite dependent actors (Meyer and Zucker 1989:100) and are often sufficiently powerful to offset owners preference for improved financial performance.

In the absence of incentives to shareholders, stakeholders tend to rely upon bank financing. However, banks too tend to favor a conservative business posture. As the suppliers of credit to a firm, banks have little incentive to fund high-risk projects. The nature of debt contracts limit their upside to the repayment of the principal and an agreed upon interest payment. On the other hand, if the project fails, they lose their investment. Since banks cannot profit from the upside return of highly successful projects, but bear the full costs of failed projects, bank debt is structurally unsuited to the high-risk uncertainties of lending to start-ups firms at the initial stages of a product life cycle (Prowse 1996).

Stakeholder governance provides core employees with incentives to invest in developing deep firm specific skills (Hall \& Soskice 2001), In return core employees are provided with internal rights such as employment security, career mobility and due process with an internal labor market. However, the establishment of stable internal and labor markets for core employees creates segmenting tendencies for non-core workers. The latter face much poorer working conditions and bear the burden of product market uncertainty. Core employees have little incentive to share the stability they enjoy with the non-core employees(Doeringer \& Piore 1994). Instead, core employees tend to rationalize and legitimize their positions in terms of 
superior skill and effort and institutionalize internal labor markets through collective action (Whittaker 1998). Similarly, while stakeholder governance clearly privileges a core group of first-tier of buyer/suppliers research shows firms operating under stakeholder governance may also establish a second tier of dependent non-core firms (Kim, Hoskisson, \& Wan 2004).

\subsection{Stakeholder outcomes under family governance}

The global prevalence of concentrated ownership in large diversified conglomerates and business groups, especially in emerging markets, has produced a 'principal-principal' literature (Young, Peng, Ahlstrohm, Bruton, \& Jiang 2008) that highlights the tension between majority and minority investors. On the one hand, because owner-managers exercise both managerial control and a direct claim on the firm's profits, they have a 'high powered' incentive to use resources efficiently (Alchian \& Demsetz 1972). There is accumulating evidence to suggest that ownership by a founding entrepreneur who is also the firm CEO is strongly related to firm performance (Amit \& Villalonga 2004; Anderson \& Reeb 2003).

On the other hand, high-powered owner incentives are effective only within a relatively limited range of ownership. Morck and Young (2003) suggest that family ownership below 10\% provides inadequate incentives for efficiency, and ownership above $20 \%$ appears to generate negative performance effects. Negative effects arise from the probability that majority owners may use their control rights to extract private benefits at the expense of minority shareholders. Shleifer and Vishny (1997) argue that the large premiums are associated with superior voting shares and other control rights, and provide evidence that controlling shareholders seek to extract private benefits. Research from emerging markets suggests the probability of expropriation is particularly high in the absence of enforceable property rights for minority shareholders. There is now substantial evidence that closely held family firms pay an equity premium to compensate 
arms-length minority investors for the risk that owner-managers may use their control rights to expropriate private benefits of control at their expense (Claessens, Djankov, \& Lang 2000; La Porta, Lopez de Silanes, \& Shleifer 1999; Lins \& Servaes 2002). To mitigate the equity capital constraint family firms frequently engage in relational contracting with banks to assure access to growth capital. Long-term relationships with a main bank were instrumental in the emergence of diversified family owned business groups in Asia (Carney \& Gedajlovic 2002).

The primary beneficiaries of family governance are the entrepreneur, his/her kin, and a network of selected insiders. The accumulation of private wealth and its transmission to succeeding generations of the family is a primary value in capitalist societies. The primacy of family is reflected in the view that the firm is an instrument of the entrepreneur and his or her family and is evident in what Chandler (1990) calls personally managed firms that demonstrate a preoccupation with wealth preservation. The focus upon wealth preservation tends to be reinforced in succeeding generations where heirs to large family fortunes are less likely to fund innovative ventures, entrench their management and seek to preserve their wealth through political lobbying (Morck, Strangeland, \& Yeung 1998).

Kinship is one of several axes of social solidarity (Granovetter 2005) and owner managers may choose to favor those in their social networks, based on religious, linguistic, political or geographical solidarity, or others with whom they have a sense of affiliation or obligation. The concentration of authority in their hands of family business owners and their exemption from the checks and balances that are applied to professional managers in stakeholder and managerial governance provide owner managers with discretion to decide the social basis of transactions. The consequence is that stakeholder outcomes are likely to be highly particularistic reflecting the personal and idiosyncratic preferences of the owner manager (Carney 2005). 
In this manner, the radius of trust (Fukuyama 1995) often extends beyond the family into a personal network of close partners who may become an associated category of beneficial stakeholders. Though owner-managers of family firms have a strong incentive to manage costs very tightly, they commonly form preferential business relations with specific customers and suppliers. In this regard, Uzzi (1997) notes that arms-length transactions are most frequently used by entrepreneurs, but they maintain close or special relations with a narrow range of partners. The comportment of owner-managers with respect to 'ordinary' and 'favored' customers and suppliers varies greatly. For instance, favored suppliers and customers may be offered preferential trade credit and access to goods in short supply (Uzzi 1997). Research on ethnic Chinese family entrepreneurship finds a preference for relational contracting in transactions related to 'big deals', extending credit or transferring a business, but most routine transactions are conducted through calculative and arm's length contracts (Redding 1990).

Secondary stakeholders Senior-executives, employees, and minority shareholders are a distant second behind family and buyer/suppliers in terms of outcomes. Senior executives in ownermanaged firms typically have less discretion relative to managers in firms where there is a separation of ownership and control. Owner-managers have strong incentives to monitor their managerial agents closely making it difficult for them to divert resources into value destroying activities or by consuming organizational perquisites (Anderson and Reeb, 2003). The personalized character of the owner-managed firm constrains its ability to offer high-powered incentives such as stock options to non-family members over concerns related to diluting family control and wealth. Third, non-family executives may face a glass ceiling since top positions are reserved for the children of the founders. Such practices can inject discord and a sense of inequity among the management team and can militate against recruiting and retaining highly 
qualified external management. In fact, the inability to reward extremely high performance creates self-selection dynamics that may impede a firm's ability to attract and retain high quality executives. Entrepreneur controlled firms must compensate professional managers for these deficiencies through increased cash compensation packages. Gomez-Meija, Larraza-Kintana and Makri, (2003) find that non-family professional CEOs in US family controlled public firms on average receive four times more income than CEOs who are family members.

Similarly, employees are rarely accorded special standing because parsimony and particularism condition the rewards provided employees in systems of entrepreneurial governance. Since owners-managers appropriate residual returns, they can be exceedingly parsimonious in offering inducements to employees. In this regard, owner-managers can bring an ownership mentality to human resource decisions and often view compensation and benefits as expenses rather than investments. In general, labor costs in family businesses tend to be significantly lower than their non-family counterparts and they report spending less on training and career development programs than other firms do.

In sum, relative to other governance systems, family governance privileges owners' personal wealth and subordinates external capital in a way that creates a characteristic capital constraint. However, released from the constraints of the accountability to arms length investors and buyer/suppliers under managerial and stakeholder governance, owner managers are free to exhibit particular and idiosyncratic tendencies that produce a variety of organizational outcomes; thus family firms have simultaneously the highest mortality rates and are among the longest lived organizations spanning several generations (Miller \& Breton-Miller 2005).

\section{Discussion}


Governance systems weigh heavily and systematically in the manner through which stakeholder distributional outcomes are made and sustained. Because governance systems vary in terms of authority and contracting mode, they affect the legitimacy, power, and kinds of tensions stakeholders can expect to meet. Our comparative review of governance systems summarized in table two summarizes some of the intra-stakeholder tensions inherent in each system of governance.

Table 2 about here

While managerial governance highlights shareholder-manager conflicts, other conflicts are also evident under this system. Under stakeholder governance creditors, suppliers, and employees enjoy a primary stake while arms length equity investors endure a subordinate position. The expropriation of minority shareholder wealth under family governance has attracted the lion's share of attention; however, its concentration of authority tends to generate idiosyncratic stakeholder tensions. In this respect, and without entering into normative debates, governance viewed from an authority perspective may shed light upon the efficacy of mechanisms available to agents to reorder stakeholder outcomes.

Two mechanisms suggest solutions to this problem: The first approach is to utilize 'market' strategies that either increase the bargaining power of a group or undertake action to reduce dependence upon a focal firm by developing alternatives. In many contexts it is given that stakeholders will leverage their relative power to improve their outcomes (Porter 1980). Yet the exercise of bargaining power must be seen as legitimate in the context within which it is 
wielded. Sustained and illegitimate use of power, such as attempts to hold-up an organization, will tend to generate countervailing powers (Gelpi 2003). Consequently, norms and conventions tend to develop among frequently transacting parties that form part of the bargaining context (McNeil 1978) which tend to moderate and mediate the exercise of power. Indeed, institutional theorists take it as axiomatic that structures of power and authority are socially constructed and power relations will be context dependent.

A second approach is to advance stakeholder interests collectively by seeking to influence the policy and legislative agenda and to encourage the state to develop legal protection for the rights of unprotected groups. This approach implies sustained processes of institutional entrepreneurship (Granovetter 2005) that require advocacy and legitimation of alternative models of firm governance and managerial practice.

We have not in this paper been much concerned with the wealth generating effects of different governance systems. Advocates of the stakeholder model of corporate governance claim that zero sum contests can be converted into positive sum games due to the competitive advantages of more inclusive and egalitarian stakeholder management. Because it mitigates the demands of capital and labor markets, stakeholder governance has attracted much attention. What is often advocated is the adoption of a stewardship approach in which managers are charged with a fiduciary responsibility to serve as a neutral coordinator of the contributions and returns of all stakeholders in the firm' while promoting the overall well being of the firm. Such advocacy is well meaning, but overlooks the primacy and hierarchical nature of stakeholder claims in managerial governance. For example, Kochan and Rubenstein (2000) lament the failure of General Motors management to transfer high productivity cooperative labor management practices that were pioneered in a joint venture with Toyota and refined in the Saturn division 
into other divisions due to multiple organizational conflicts and the absence of a strong legal foundation for stakeholder management. Pfeffer (1991) too vents frustration at American managers for their resistance to employee incentives such as profit sharing employee, stock ownership and knowledge-based pay despite accumulating evidence of their positive contribution to firm performance.

Successful management practices that thrive in stakeholder governance systems are not easily accommodated without substantial modification in managerially governed firms (Gooderham, Nordhaug, \& Ringdal 1999). Advocates of the stakeholder management model underestimate the historical origins of this governance system and the requirements for a complex institutional and legal architecture needed to support the model. The courts too have found it difficult to formulate and enforce 'fiduciary duties of sufficient refinement to assure that managers behave more efficiently and fairly' (Hansmann \& Kraakman 2004). Stakeholder models in favor of better employee outcomes seem to flounder on the diversity of employee intertests, and the development of a unitary bargaining position seems elusive.

\section{Conclusion}

We propose that firms are arenas for conflict among rivalrous stakeholders. While much literature has focused upon the conflict between executives and the owners and stewards of capital and between executives and employees we have assembled and reviewed a disparate literature that directly and indirectly identifies numerous intra-stakeholder conflicts. Our intended contribution is to review governance conflicts from an authority perspective in a manner that reveals many intra-stakeholder conflicts as inherent within particular governance systems. Governance viewed in this way sheds light on a divergent shareholder value and stakeholder management literatures that have largely ceased to inform one another. The 
implications of our view suggest no easy solutions for the myriad conflicts found in various systems of governance but we believe that stakeholder conflict viewed from this perspective may put future research on a firmer footing.

While some scholars argue a corporate governance convergence thesis that suggests "the triumph of the shareholder-oriented model of the corporation over its principal competitors is now assured" (Hansmann and Kraakman, 2004:67) we are unconvinced and point to a growing literature suggesting continuing divergence in systems of governance around the world (\{Whitley, 1999 \#8057\}\{Hollingsworth, 1997 \#1671\} \{Guillen, 2001 \#1674\}\{Khanna, 2003 \#2686\} \{ Consequently, understanding cross-national differences in distributional outcomes among and between stakeholder groups is likely to remain continuing focus for governance research. Moreover, as the varieties of capitalism literature has established (\{Boyer, 2005 \#10972\} Carney, 2009 \#11168)\} there is, within any particular nation state a plurality of institutional architectures that will support a diverse array of governance and organizational forms and we hope and suggest that stakeholder differences can be better appreciated through the authority based perspective outlined this paper. 


\section{References}

Aguilera, R., \& Jackson, G. (2003). The cross national diversity of corporate governance:dimensions and determinants. Academy of Management Review, 28, 447-445.

Aguilera, R. V., Filatotchev, I., Gospel, H., \& Jackson, G. (2008). An Organizational Approach to Comparative Corporate Governance: Costs, Contingencies, and Complementarities. Organization Science, 19, 475-494.

Alchian, A. A., \& Demsetz, H. (1972). Production, information costs, and economic organization. American Economic Review, 62, 777-795.

Allen, F., \& Gale, D. (2000). Comparing Financial Systems. Cambridge, Ma: The MIT Press.

Amit, R., \& Villalonga, B. (2004). How Do Family Ownership, Control, and Management Affect Firm Value? Journal of Financial Economics, 80, 385-417.

Anderson, R. C., \& Reeb, D. M. (2003). Founding family ownership and firm performance: Evidence from the S\&P 500. Journal of Finance, 58, 1301-1328.

Arya, A., \& Sun, H.-L. (2004). Stock Option Repricing: Heads I Win, Tails You Lose. Journal of Business Ethics, 50, 297-312.

Barker, J. R. (1993). Tightening the iron cage: Concertive action in self-managed teams. Administrative Science Quarterly, 38, 408-437.

Bebchuk, L. A., \& Jolls, C. (1999). Managerial value diversion and shareholder wealth. Journal of Law, Economics and Organization, 15, 487-.

Bebchuk, L. A., \& Roe, M. J. (1999). A Theory of Path Dependence in Corporate Ownership and Governance. Stanford Law Review, 52, 127-170.

Berglöf, E., \& Perotti, E. ( 1994). The governance structure of the Japanese financial keiretsu. Journal of Financial Economics, 36, 259-284.

Bergloff, E., \& von Thadden, E. L. (1994). Short Term vs. Long Term Interest: Capital Structure with Multiple Investors. Quarterly Journal of Economics, 109, 1055-1084.

Berman, S. L., Wicks, A. C., Kotha, S., \& Jones, T. M. (1999). Does Stakeholder Orientation Matter? The Relationship between Stakeholder Management Models and Firm Financial Performance. Academy of Management Journal, 42, 488-506.

Biggart, N. W., \& Delbridge, R. (2004). Systems of Exchange. Academy of Management Review, 29, 28-49.

Blasi, J., Kruse, D., \& Bernstein, A. (2003). In the company of owners: The truth about stock options and why every employee should have them. New York: Basic Books.

Boyer, R. (2005). How and why capitalisms differ. Economy and society, 34, 509-557.

Carney, M. (2005). Corporate governance and competitive advantage in family-controlled firms. Entrepreneurship: Theory and Practice, 29, 249-265.

Carney, M., \& Gedajlovic, E. (2002). The Co-Evolution of Institutional Environments and Organizational Strategies: The Rise of Family Business Groups in the ASEAN Region. Organization Studies, 23, 1-31.

Chandler, A. D. (1990). Scale and Scope: The Dynamics of Industrial Competition. Cambridge: Harvard University Press.

Charkham, J. P. (1994). Keeping Good Company : A Study of Corporate Governance in Five Countries. Oxford: Oxford University Press.

Chua, J. H., Chrisman, J. J., \& Sharma, P. (1999). Defining family business by behaviour. Entrepreneurship: Theory and Practise, 23, 19-39. 
Claessens, S., Djankov, S., \& Lang, L. H. P. (2000). The separation of ownership and control in East Asian corporations. Journal of Financial Economics, 58, 81-112.

Coff, R. W. (1999). When competitive advantage doesn't lead to performance: The resourcebased view and stakeholder bargaining power. Organization Science, 10, 119.

Coffee, J. C., Jr. (2000). Convergence and its Critics: What are the Preconditions for the Separation of Ownership and Control: Columbia Law School; Center for Law and economics.

Combs, J. G., \& Skill, M. S. (2003). Managerialist and human capital explanation for key executive pay premiums: a contingency perspective. Academy of Management Journal, 46, 63-73.

Commons, J. R. (1934). Institutional Economics. Madison: University of Wisconsin Press.

Dalton, D. R., Daily, C. M., Certo, S. T., \& Roengpitya, R. (2003). Meta-analyses of financial performance and equity: Fusion or confusion? Academy of Management Journal, 46, 13.

Demsetz, H., \& Lehn, K. (1985). The Structure of Corporate Ownership: Causes and Consequences. The Journal of Political Economy, 93, 1155.

Dharwadkar, B., George, G., \& Brandes, P. (2000). Privatization in emerging economies: An agency theory perspective. Academy of Management Review, 25, 650-669.

Doeringer, P. B., \& Piore, M. J. (1994). Internal Labor Markets and Manpower Analysis. Lexington, MA: : M. E. Sharpe.

Donaldson, T., \& Preston, L. E. (1995). The Stakeholder Theory of the Corporation: Concepts, Evidence and Implications. Academy of Management Review, 20, 65-91.

Dyer, J. H. (1996). Does governance matter? Keiretsu alliances and asset specificity as sources of Japanese competitive advantage. Organization Science, 7, 649-666.

Dyer, J. H., \& Singh, H. (1998). The relational view: Cooperative strategy and sources of interorganizational competitive advantage. Academy of Management Review, 23, 660679.

Edwards, R. (1979). Contested terrain : the transformation of the workplace in the twentieth century. New York: Basic Books.

Eisenhardt, K. M. (1989). Agency theory: An assessment and review. Academy of Management Review, 14, 57-74.

Engela, E., Hayes, R. B., \& Wang, X. (2007). The Sarbanes-Oxley Act and firms' going-private decisions. Journal of Accounting and Economics

44, 116-145.

Fama, E. F., \& Jensen, M. C. (1983). Separation of ownership and control. Journal of Law and Economics, 26, 301-326.

Finkelstein, S. (1992). Power in Top Management Teams: Dimensions, Measurement, and Validation. Academy of Management Journal, 35, 505-538.

Fiss, P., \& Zajac, E. J. (2004). The diffusion of ideas over contested terrain: the (non) adoption of shareholder value orientation along German firm. Administrative Science Quarterly.

Fligstein, N. (2001). The Architecture of Markets : An Economic Sociology of Twenty-First Century Capitalist Societies. Princeton, N.J. : Princeton University Press.

Freeman, A. (1984). Strategic Management: A Stakeholder Approach. Boston: Pitman

Freeman, R. E., Wicks, A. C., \& Parmar, B. (2004). Stakeholder Theory and "The Corporate Objective Revisited". Organization Science, 15, 364.

Fukuyama, F. (1995). Trust: The Social Virtues and the Creation of Prosperity. New York: Free Press. 
Gedajlovic, E., Lubatkin, M. H., \& Schulze, W. S. (2005). Crossing the Threshold from Founder Management to Professional Management: A Governance Perspective. Journal of Management Studies, 41, 899-.

Gedajlovic, E., \& Shapiro, D. (1998). Management and ownership effects: Evidence from five countries. Strategic Management Journal, 19 533-553.

Gelpi, C. (2003). The Power of Legitimacy : Assessing the Role of Norms in Crisis Bargaining. Princeton, NJ Princeton University Press.

Gereffi, G. (2001). Shifting governance structures in global commodity chains, with special reference to the internet. The American Behavioural Scientist, 44, 1616-1637.

Gerlach, M. L. (1992). Alliance Capitalism: the social organization of Japanese business. Berkely, CA: University of California press.

Gomez-Mejia, L., Larraza-Kintana, M., \& Makri, M. (2003). The determinants of executive compensation in family-controlled public corporations. Academy of Management Journal, 46, 226-237.

Gooderham, P. N., Nordhaug, O., \& Ringdal, K. (1999). Insitutional and rational determinants of organizational practises: Human resource management in European firms. Administrative Science Quarterly, 44, 507-531.

Gourevitch, P. A., \& Shinn, J. (2005). Political power and corporate control: The new global politics of corporate governance. Princeton, New Jersey Princeton University Press.

Granovetter, M. (2005). Business groups and social organization. In N. J. Smelser, \& R. Swedburg (Eds.), The handbook of economic sociology 2ed. Princeton: Princeton University Press.

Hall, B. J., \& Liebman, J. B. (1998). Are CEOs Really Paid Like Bureaucrats? The Quarterly Journal of Economics, 113, 653-691.

Hall, P., \& Soskice, D. (2001). Varieties of Capitalism: the institutional foundations of comparative advantage. Oxford: Oxford University Press.

Hamilton, G. G., \& Biggart, N. W. (1988). Market, culture and authority: A comparative analysis of management in the Far East. American Journal of Sociology, 94, S52-S94.

Hansmann, H., \& Kraakman, R. (2004). The end of history for corporate law. In J. N. Gordon, \& M. J. Roe (Eds.), Convergence and persistence in corporate governance: 33-68. Cambridge: Cambridge University Press.

Harris, M., \& Raviv, A. (1991). The Theory of Capital Structure. Journal of Finance, 46, 297355.

Heetderks, T. D., \& Martin, J. E. (1991). Employee perceptions of the effects of a two-tier wage structure Journal of Labor Research, 12, 279-295.

Hillman, A. J., \& Keim, G. D. (2001). Shareholder value, stakeholder management, and social issues: What's the bottom line? Strategic Management Journal, 22, 125-139.

Hinings, C. R., \& Greenwood, R. (2002). Disconnects and Consequences in Organization Theory? Administrative Science Quarterly, 47, 411-421.

Hoskisson, R. E., Hitt, M. A., Johnson, R. A., \& Grossman, W. (2002). Conflicting voices: The effects of institutional ownership heterogeneity and internal governance on corporate innovation strategies. Academy of Management Journal, 45, 697-716.

Hoskisson, R. E., \& Turk, T. A. (1990). Corporate Restructuring: Governance and Control Limits of the Internal Capital Market. Academy of Management Review, 15, 459-477.

Jacoby, S. M., \& Mitchell, D. J. B. (1990). Sticky Stories: Economic Explanations Of Employment And Wage Rigidity. The American Economic Review, 80, 33-37. 
Jarrell, G. A., \& Poulsen, A. B. (1988). Dual-Class Recapitalizations as Antitakeover Mechanisms: The Recent Evidence. Journal of Financial Economics, 20, 129-152.

Jensen, M. (1989). The eclipse of the public corporation. Harvard Business Review, May-June:, 67-74.

Jensen, M. C. (1998). Foundations of Organizational Strategy. Cambridge, Mass: Harvard University Press.

Jensen, M. C. (2000). A Theory of the Firm : Governance, Residual Claims, and Organizational Forms. Cambridge, MA Harvard University Press.

Jensen, M. C. (2002). Value Maximization, Stakeholder Theory, and the Corporate Objective Function. Business Ethics Quarterly, 12, 235-256.

Jensen, M. C., \& Meckling, W. H. (1976). Theory of the firm: Managerial behavior, agency costs and ownership structure. Journal of Financial Economics, 3, 305-360.

Jones, T. M., \& Wicks, A. C. (1999). Convergent Stakeholder Theory. Academy of Management Review, 24, 206-221.

Kester, C. W. (1992). Industrial groups as systems of contractual governance. Oxford Review of Economic Policy, 8, 24-44.

Khanna, T., Kogan, J., \& Palepu, K. (2003). Globalization and Similarities in Corporate Governance: A Cross-Country Analysis. Review of Economics and Statistics, 88, 69-90.

Kim, H., Hoskisson, R., \& Wan, W. P. (2004). Power dependence, diversification strategy, and performance in keiretsu member firms. Strategic Management Journal, 25, 613-636.

Kochan, T. A., \& Rubinstein, S. A. (2000). Toward a stakeholder theory of the firm: The Saturn partnership. Organization Science, 11, 367-386.

Kogut, B. (1988). Joint ventures: Theoretical and empirical perspectives. Strategic Management Journal, 9, 319-332.

Krosznera, R. S., \& Strahan, P. E. (2001). Bankers on boards: monitoring, conflicts of interest, and lender liability. Journal of Financial Economics, 62, 415-452.

La Porta, R., Lopez de Silanes, F., \& Shleifer, A. (1999). Corporate governance around the world. Journal of Finance, 54, 471-517.

Licht, A. N. (2001). The Mother of all Path Dependencies: Toward a Cross-Cultural Theory of Corporate Governance Systems. Delaware Journal of Corporate Law, 26, 147-205.

Lie, E. (2005). On the Timing of CEO Stock Option Awards. Management Science, 51, 802-812.

Lins, K. V., \& Servaes, H. (2002). Is Corporate Diversification Beneficial in Emerging Markets? Financial Management, 31, 5-31.

Macneil, I. R. (1978). Contracts: Adjustment of long-term economic relations under classical and neo-classical, and relational contract law. Northwestern University Law Review, 72, 854905.

McGuire, J. B., Sundgren, A., \& Schneeweis, T. (1988). Corporate social responsibility and firm financial performance. Academy of Management Journal, 31, 854-872.

McNeil, K. (1978). Understanding Organizational Power: Building on the Weberian Legacy. Administrative Science Quarterly, 23, 65-90.

Meyer, M. W., Zucker LG. (1989). Permanently Failing Organizations. Newbury Park, CA: Sage.

Miller, D., \& Breton-Miller, I. (2005). Managing for the Long Run: Lessons in Competitive Advantage from Great Family Business. Boston, Mass.: Harvard Business School Press.

Mintzberg, H. (1994). The Rise and Fall of Strategic Planning. Englewood Cliffs: Prentice Hall. 
Mitchell, R. K., Agle, B. R., \& Wood, D. J. (1997). Toward a theory of stakeholder identification and salience: Defining the principle of who and what really counts. Academy of Management Review, 22, 853-886.

Morck, R., \& Yeung, B. (2003). Agency problems in large family business groups. Entrepreneurship Theory and Practice, 27, 367-383.

Morck, R. K., Strangeland, D. A., \& Yeung, B. (1998). Inherited wealth, corporate control and economic growth: The Canadian disease, National Bureau of Economic Research. www.nber.org/papersw6814.

Morck, R. K., Wolfenzon, D., \& Yeung, B. (2005). Corporate governance, economic entrenchment, and growth Journal of Economic Literature, 43, 655-720.

Pfeffer, J. (1994). Competitive advantage through people: Unleashing the power of the work force. Boston: Harvard Business School Press.

Poppo, L., \& Zenger, T. (2002). Do formal contracts and relational governance function as substitutes or complements. Strategic Management Journal, 23, 707-725.

Porac, J. F., Wade, J. B., \& Pollock, T. G. (1999). Industry Categories and the Politics of the Comparable Firm in CEO Compensation. Administrative Science Quarterly, 44, 112-144.

Porter, M. E. (1980). Competitive Strategy. New York: Free Press.

Porter, M. E. (1992). Capital disadvantage: America's failing capital investment system. In M. E. Porter (Ed.), On Competition: 431-467. Boston: Harvard Business Review Book.

Post, J. E., Preston, L. E., \& Sachs, S. (2002). Redefining the Corporation: Stakeholder Management and Organizational Wealth. Stanford, CA:: Stanford University Press. .

Prowse, S., D. (1996). Corporate finance in international perspective: Legal and regulatory influences on financial system development. Federal Reserve Bank of Dallas Economic Review2-16.

Rappaport, A. (1990). The staying power of the public corporation Harvard business review96-104.

Redding, G. (1990). The spirit of Chinese capitalism. New York:: De Gruyter.

Renneboog, L., \& Szilagyi, P. G. (2008). Corporate Restructuring and Bondholder Wealth. European Financial Management, 14, 792-819.

Ring, P. S., \& Van De Ven, A. (1992). Structuring cooperative relationships between organizations. Strategic Management Journal, 13, 483-498.

Roe, M. J. (1994). Strong Managers, Weak Owners. Princeton:: Princeton University Press.

Roe, M. J. (2003). Political determinants of corporate governance: Political context and corporate impact. New York: Oxford University Press.

Rousseau, D. M., \& Shperling, Z. (2004). Ownership and the Changing Employment Relationship: Why Stylized Notions of Labor No Longer Generally Apply - A Reply to Zardkoohi and Paetzold. Academy of Management Review, 29, 562.

Sabel, C. (2004). Ungoverned production: an American view of the novel universalism of Japanese production methods and their awkward fit with current forms of corporate governance. In J. N. Gordon, \& M. J. Roe (Eds.), Convergence and persistence in corporate governance: 310-329. Cambridge: Cambridge University Press.

Schulze, W., Lubatkin, M. H., Dino, R. N., \& Buchholtz, A. K. (2001). Agency relationships in family firms: Theory and evidence Organization Science, 12, 99-116.

Shleifer, A., \& Vishny, R. W. (1997). A survey of corporate governance. The Journal of Finance, 52, 737-783.

Sundaram, A. K., \& Inkpen, A. C. (2004). The Corporate Objective Revisited. Organization Science, 15, 350. 
Thomsen, S., \& Pedersen, T. (2000). Ownership Structure and Economic Performance in the Largest European Companies. Strategic Management Journal, 21, 689-705.

Useem, M. (1993). Executive defense: shareholder power and corporate reorganization. Cambridge. MA: Harvard University Press.

Uzzi, B. (1997). Social structure and competition in interfirm networks: The paradox of embeddedness. Administrative Science Quarterly, 42, 35-67.

Walsh, J. P., \& Seward, J. K. (1990). On the efficiency of internal and external control mechanisms. Academy of Management Review, 15:, 421-458.

Waterman, R. H., Jr., Waterman, J. A., \& Collard, B. A. (1994). Toward a Career-Resilient Workforce. Harvard Business Review, 72, 87-95.

Westphal, J. D., \& Zajac, E., J. (1998). The symbolic management of stockholders: corporate governance reforms and shareholder reactions. Administrative Science Quarterly, 43.

Whitley, R. D. (1992). Business Systems in East Asia: Firms, Markets and Societies. London: Sage.

Whittaker, D. H. (1998). Labour Unions and industrial relations in Japan: crumbling pillar or forging a 'third way'. Industrial Relations Journal, 29, 280-293.

Williamson, O. E. (1975). Markets and hierarchies: Analysis and antitrust implications. New York: Free Press.

Williamson, O. E. (1985). The economic institutions of capitalism: Firms, markets, relational contracting. New York: Free Press.

Williamson, O. E., Aoki, M., \& Gustafsson, B. (Eds.). (1990). The Firm as a Nexus of Treaties. London Sage.

Woidtke, T. (2002). Agents watching agents? Evidence from pension fund ownership and firm value. Journal of Financial Economics, 63, 99-131.

Wolfe, R., \& Putler, D. (2002). How tight are the ties that bind stakeholder groups? Organization science, 13, 64-80.

Young, M., Peng, M., Ahlstrohm, D., Bruton, G. D., \& Jiang, Y. (2008). Corporate governance in emerging economies: a review of the principal-principal perspective. Journal of management studies, 45, 196-220.

Zajac, E. J., \& Westphal, J. D. (1994). The costs and benefits of managerial incentives and monitoring in large U.S. corporations: When is more not better? Strategic Management Journal, 15, 121. 
Table 1: Comparative Table of the Differing Governance Perspectives

\begin{tabular}{|c|c|c|}
\hline & Shareholder Perspective & Stakeholder Perspective \\
\hline $\begin{array}{l}\text { Stakeholder } \\
\text { Outcome }\end{array}$ & $\begin{array}{c}\text { Singular: Specific } \\
\text { Shareholder returns }{ }^{i}\end{array}$ & $\begin{array}{c}\text { Multiple: Holistic } \\
\text { Distribution to all stakeholders }\end{array}$ \\
\hline Purpose of Firm & $\begin{array}{l}\text { An instrument for shareholder wealth } \\
\text { maximization }\end{array}$ & $\begin{array}{c}\text { A locus in relation to wider external } \\
\text { stakeholders' interests }{ }^{\text {iv }}\end{array}$ \\
\hline $\begin{array}{c}\text { Theoretical } \\
\text { Underpinnings }\end{array}$ & $\begin{array}{c}\text { Transaction Cost Economics }{ }^{\mathrm{v}} ; \\
\text { Agency Theory: Managerial Agency(Type 1) } \\
{ }_{\text {vi }} \text {; Principal-Principal Agency (Type 2) }\end{array}$ & $\begin{array}{c}\text { System theory }{ }^{\text {viii }} \\
\text { Stakeholder Theory }{ }^{\text {ix }}\end{array}$ \\
\hline Key assumption & Dispersed shareholders as rightful owners vi & $\begin{array}{l}\text { All stakeholders have equitable } \\
\text { rights ix }\end{array}$ \\
\hline Interaction & Antagonistic $^{\mathrm{x}}$; Arms length ${ }^{\mathrm{xi}}$ & Relational ${ }^{\text {xii }}$ \\
\hline $\begin{array}{l}\text { Nature of } \\
\text { Stakeholder } \\
\text { Conflict }\end{array}$ & $\begin{array}{c}\text { Dyadic: } \\
\text { Owner - Manager (Type 1) }{ }^{\text {xiii }} \\
\text { Owner - Owner (Type 2) }\end{array}$ & Inter-related ${ }^{\mathrm{xv}}$ \\
\hline $\begin{array}{l}\text { Examples of } \\
\text { intra- } \\
\text { stakeholder } \\
\text { conflicts }\end{array}$ & $\begin{array}{l}\text { Owners vs. Managers (Type 1) } \\
\text { Voting rights vs. Cashflow rights (Type 2) } \\
\text { xvii } \\
\text { Debt vs. Equity holders (Type } 1 \& 2)^{\text {xiii }} \\
\text { Intra-ownership type conflicts (Type 2) } \\
\text { Long-term vs. Short-term investors (Type 2) } \\
\text { xx }\end{array}$ & $\begin{array}{l}\text { Differing perspectives of multiple } \\
\text { stakeholders xxi } \\
\text { Unmonitored and unaccountable } \\
\text { managers }{ }^{\text {xxii }}\end{array}$ \\
\hline $\begin{array}{c}\text { Primary } \\
\text { Stakeholder }\end{array}$ & Shareholder ${ }^{\text {xxiii }}$ & No specific stakeholder group(s) \\
\hline $\begin{array}{c}\text { Secondary } \\
\text { stakeholder }\end{array}$ & Managers ${ }^{\text {iii }}$ & No specific stakeholder group(s) \\
\hline Authority & Managers for dispersed shareholder ${ }^{\text {xvi }}$ & Network $^{\text {xxiv }}$ \\
\hline Contracting mode & Formal, Arms length ${ }^{\mathrm{xxv}}$ & Relational Contracting $^{\text {xviii }}$ \\
\hline $\begin{array}{c}\text { Governance } \\
\text { focus } \\
\end{array}$ & $\begin{array}{c}\text { Mitigating Agency cost } \\
\text { Minimizing transaction cost }^{\text {iv }}\end{array}$ & $\begin{array}{l}\text { Identifying \& resolving stakeholder } \\
\text { concerns }\end{array}$ \\
\hline $\begin{array}{l}\text { Governance } \\
\text { mechanism }\end{array}$ & $\begin{array}{c}\text { Managerial Monitoring } \\
\text { Alignment of Incentives xxvi }\end{array}$ & $\begin{array}{l}\text { Network; Control embedded in } \\
\text { lasting relationships }\end{array}$ \\
\hline Contributions & $\begin{array}{c}\text { Ease of modeling }{ }^{\text {xxviii }} \\
\text { Clear quantifiable outcome }\end{array}$ & $\begin{array}{c}\text { Realistic } \\
\text { Includes all possible factors }\end{array}$ \\
\hline Limitations & Ignores most external factors ${ }^{x x i i}$ & $\begin{array}{l}\text { Complexity in modeling }{ }^{\text {xxix }} \text {; } \\
\text { Unclear, emergent outcome }\end{array}$ \\
\hline
\end{tabular}

${ }^{\mathrm{i}}$ Jensen, 2002

ii Kochan \& Rubinstein, 2000

${ }^{\text {iii }}$ Friedman, 2007

${ }^{\text {iv }}$ Letza, Xiuping \& Kirkbride, 2004

${ }^{\mathrm{v}}$ Williamson, 1985

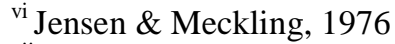

vii Dharwadkar, George \& Brandes, 2000

viii Trist, 1981

${ }^{\text {ix }}$ Freeman, 1984

${ }^{\mathrm{x}}$ Galbraith, 1977

${ }^{x i}$ Jacoby \& Mitchell, 1990

xii Post, Preston \& Sachs, 2002

xiii Shleifer \& Vishny, 1997

${ }^{\text {xiv }}$ Faccio, Lang \& Young, 2001

${ }^{\mathrm{xv}}$ Ring \& Van De Ven, 1992
${ }^{\mathrm{xvi}}$ Becht, Bolton \& Roell, 2003

xvii Jarrell \& Poulson, 1988; Gompers, Ishii \& Metrick, 2004

${ }^{\text {xviii }}$ Harris \& Raviv, 1991

${ }^{\mathrm{xix}}$ Thomsen \& Pedersen, 2000

${ }^{\mathrm{xx}}$ Hoskisson, Hitt, Johnson \& Grossman, 2002

${ }^{x x i}$ Schwarzkopf, 2006

${ }^{x x i i}$ Agle, Donaldson, Freeman, Jensen, Mitchell \& Wood, 2008

xxiii Fligstein, 2001

${ }^{\text {xxiv }}$ Charkham, 1994

${ }^{\mathrm{xxv}}$ Biggart \& Delbridge, 2004

${ }^{x x v i}$ Himmelberg, Hubbard \& Palia, 1999; Jensen \& Murphy, 1990

xxvii Sabel, 2004

xxviii Daily, Dalton \& Cannella, 2003

${ }^{x x i x}$ Phillips \& Reichart, 2000

${ }^{\mathrm{xxx}}$ Sundaram \& Inkpen, 2004 
Table 2: Comparative corporate governance systems and stakeholder conflict

\begin{tabular}{|c|c|c|c|}
\hline $\begin{array}{c}\text { Authority } \\
\text { structure }\end{array}$ & $\begin{array}{c}\text { Managerial } \\
\text { Stakepholed ownership } \\
\text { Executive control }\end{array}$ & $\begin{array}{c}\text { Separated ownership } \\
\text { Insider control }\end{array}$ & $\begin{array}{c}\text { Family } \\
\text { mode } \\
\text { montrated ownership } \\
\text { Insider control }\end{array}$ \\
\hline $\begin{array}{c}\text { Inter - } \\
\text { stakeholder } \\
\text { conflict }\end{array}$ & $\begin{array}{c}\text { Equity investors vs. } \\
\text { Professional executives } \\
\text { Equity investors vs. } \\
\text { Employees }\end{array}$ & $\begin{array}{c}\text { Equity investors vs. } \\
\text { Insider stakeholders }\end{array}$ & Family vs. Outsiders \\
\hline $\begin{array}{c}\text { Intra - } \\
\text { stakeholder } \\
\text { conflict }\end{array}$ & $\begin{array}{c}\text { Knowledge vs. Routine } \\
\text { employees } \\
\text { Senior vs. Junior } \\
\text { employees } \\
\text { Creditors vs. Equity } \\
\text { investors }\end{array}$ & $\begin{array}{c}\text { Creditors vs. Equity } \\
\text { investors } \\
\text { Core vs. Noncore } \\
\text { employees } \\
\text { Core vs. Noncore } \\
\text { buyer/suppliers }\end{array}$ & $\begin{array}{c}\text { Majority vs. Minority } \\
\text { equity investors } \\
\text { Family vs. Professional } \\
\text { executives } \\
\text { Arm's length vs. } \\
\text { Relational } \\
\text { buyer/suppliers }\end{array}$ \\
\hline
\end{tabular}

